\title{
WEIGHTLESS PROCESSING OF QUANTIZED SIGNAL LOAD
}

DOI: |0.36724/2072-8735-202|-|5-|-48-5 |

\section{Vladimir I. Filatov,}

Bauman Moscow State Technical University, Moscow, Russia, vfill0@mail.ru

\begin{abstract}
Alexander S. Nekrasov, Military Academy of the Strategic Missile Forces Academy named after Peter the Great, Balashikha, Moscow region, Russia, sanya.nekrasov.1992@mail.ru
\end{abstract}

Irina A. Rudzit, Bauman Moscow State Technical University, Moscow, Russia, rudzit@bmstu.ru

Daria A. Kondrashova, Bauman Moscow State Technical University, Moscow, Russia, darina.k.a@mail.ru
Manuscript received 26 October 2020; Accepted 20 December 2020

\begin{abstract}
Optimal methods for processing input information signals often involve operations, implementation of which is extremely difficult and significantly increases the requirements for automated information processing systems. However, the use of various approaches to solving this problem has led to the appearance of synthesized methods for processing a sequence of signals that allow solving the detection problem with the required quality without significant hardware complications. The article considers a method for weightless processing packets of input quantized signals, which allows us to evaluate the potential (limit) quality of information processing and quantify the amount of loss of this quality when excluding certain operations. The considered method is given with a reasonable structure of implemented devices in practice. A special feature of weightless signal processing is analysis of increasing unit density in a fixed interval of close positions, which gives information about the possible presence of an information signal. To identify this factor, two logical criteria are used, such as "m out of $m$ " and "n out of $m$ ", which will be described in this article.
\end{abstract}

Information about authors:

Vladimir I. Filatov, candidate of technical Sciences, associate Professor at the Bauman Moscow State Technical University, faculty of Informatics and control systems, Department of information protection, Moscow, Russia

Alexander S. Nekrasov, teacher, Military Academy of the Strategic Missile Forces Academy named after Peter the Great, Balashikha,

Moscow region, Russia

Irina A. Rudzit, teacher, Bauman Moscow State Technical University, Moscow, Russia

Daria A. Kondrashova, student, Bauman Moscow State Technical University, faculty of Informatics and control systems, Department of information protection, Moscow, Russia

Для цитирования:

Филатов В.И., Некрасов А.С., Рудзит И.А., Кондрашова Д.А. Безвесовая обработка пачки квантованных сигналов // Т-Сотт: Телекоммуникации и транспорт. 202I. Том I5. №I. С. 48-5I.

For citation:

Filatov V.I., Nekrasov A.S., Rudzit I.A., Kondrashova D.A. (202I) Weightless processing of quantized signal load. T-Comm, vol. I5, no.I, Pp. 48-5I. (in Russian) 
Potential possibilities of detection algorithm

$\sum_{i=1}^{M} n_{j} X_{i}>z_{0}$.

are realized if figures $M$ and $n_{i}$ correspond to those of the synthesis. However, the value of signals in any load $M$ is random, depending on the distance to detection objects, their reflective features and location conditions. Coefficient $n_{i}$ values are also known only approximately. Hence, the figures of optimal detection quality in real information processing conditions can prove extremely low. Therefore, a far easier way of detection is applied in practice, which is not critical for the $n_{i}$ and $\mathrm{M}$ parameters.

For the case of weight values $n_{i}$ we take $n_{1}=n_{2}=\ldots=n_{M}=1$. The approximation corresponds to the algorithm of weightless processing

$$
\sum_{i=1}^{M} X_{j} \geq z_{0}
$$

the main part of which is evaluation of the number of single periods in $M$ close positions. If this value is no less than the limit $Z_{0}=n$, the hypothesis $\mathrm{H}_{1}{ }^{*}$ is considered correct, otherwise $-\mathrm{H}_{0}{ }^{*}$. The detector, realizing the logical parameter $\langle n$ out of $m »$ is shown in fig. 1:

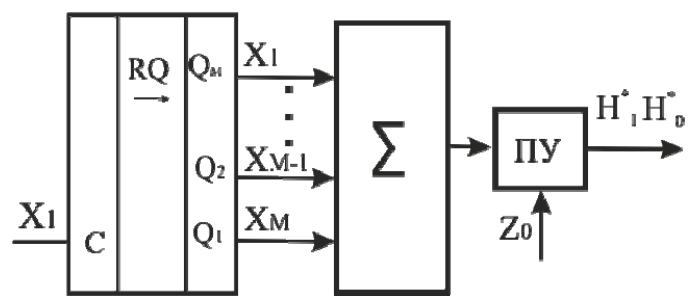

Fig. 1. The detector of quantized signal load on the logical parameter «n out of $m »$

Further algorithm simplification is caused by rejecting the whole $\mathrm{M}$ integrity of periods. The only distinctive feature of a signal load compared to interference load is the increase in unit density in a certain interval of positions. Processing the periods in this case is determined by calculating the start and final point of the load.

Hence, the total increase in density in a fixed interval of close positions provides information for the possible object to be detected. To detect this fact, logical parameters such as «m out of $m »(« m / m »)$ and «n out of $m »(\langle n / m »)$. According to the parameter $\langle m$ out of $m »$, the start of the load is fixed in case there are $m$ units in $m$ close positions.

Fig. 2a illustrates the realization of quantized periods $X_{1}$, at certain time codes $t_{i}$. Let us consider the principle of load start detection, based on the logical parameter «4 out of 4 ». Ensuring this condition primarily deals with evaluating the code combination of the last four positions. Thus, in the time code $t_{i}=t_{5}$ for the period $X_{5}$ code combination 0101 is analyzed, for which logical parameter " 4 out of 4 » is invalid. At the next discrete time code $t_{i}=t_{6}$ code combination 1011 will be analyzed, which also fails to meet the logical parameter «4 out of $4 »$.

Obviously, the logical parameter «4 out of 4» will be correct at $t_{i}=t_{8}$. Generally, the condition «m out of $m »$ is correct for the final quantized period of the connected unit subsequence. At the moment of the logical parameter « $m$ out of $m$ » being correct, the hypothesis $\mathrm{H}_{\mathrm{H \Pi}}^{*}$ is accepted («load start»). a)
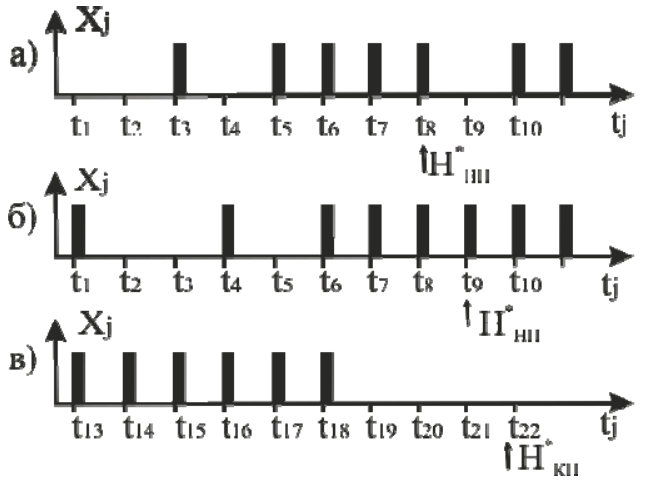

$t_{4}=0010$

$\mathrm{t}_{5}=0101$

$t_{6}=1011$

$\mathrm{t}_{7}=0111$

$\mathrm{t}_{8}=1111 \quad \mathrm{H}_{\mathrm{HH}}^{\mathrm{t}}$

$\mathrm{t}_{6}=100101$

$\mathrm{t}_{7}=001011$

$\mathrm{t}_{\mathrm{s}}=010111$

t9 $-101111 \mathrm{H}_{\text {HII }}$

$\mathrm{t}_{19}=1110$

$\mathrm{t}_{20}-1100$

$\mathrm{t}_{21}=1000$

$\mathrm{t}_{22}=0000 \mathrm{H}_{\mathrm{KI}}$

Fig. 2. Samples of detecting the start and the end of quantized signal load based on logical parameters:

a - detecting the load start based on the parameter «4 out of $4 »$;

$\mathrm{b}$ - detecting the load start based on the parameter «4 out of $6 » ;$ $\mathrm{c}-$ detecting the load start based on the parameter $k=4$

According to the logical parameter «n out of $m$ », the load start is fixed, if $m$ close positions have no less than $n$ units. The additional requirement is normally a one in the first position. The principle of load start detection according to the logical parameter « 4 out of 6 » is illustrated in fig. 2 b. In case there is an additional requirement of the starting symbol being «one», the requirement for logical parameter $« 4$ out of $6 »$ will be met at $t_{i}=t_{9}$.

After the load start symbol is fixed, its end is searched according to the parameter accepted.

The detection parameter for the load end is based on the decrease in unit density at the end of the signal load. According to this parameter, the decision upon the load end $\left(\mathrm{H}_{\mathrm{K}}^{*}\right)$ is made, based on the presence of $k$ zeros in $k$ close positions. Graphic illustration of the load end detection principle according to the logical parameter $k=4$ is in Fig. 2c.

The detector of quantized signal load (fig. 3), realizing the parameter $« n / m-k »$, involves logical schemes of load start $(n / m)$ and end $(k)$ detection, trigger $T$ and two logical elements $\langle I\rangle$.

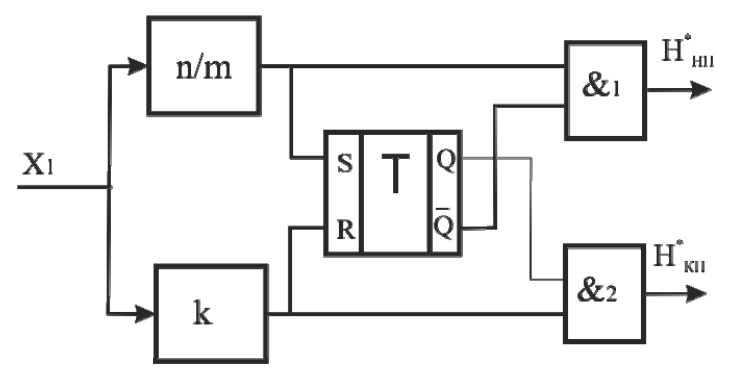

Fig. 3. Detector, realizing the logical parameter $« n / m-k »$

Suppose the trigger is in zero position, where signal output $\mathrm{H}^{*}$ КП is forbidden (load end) and the requirement for $\mathrm{H}_{\mathrm{H \Pi}}^{*}$ signal passage to the device output (load start) is provided.

The realization of load start and end detectors is determined by the given values of parameters $n, m, k$ according to which logical schemes are synthesize. Suppose the signal load detection is now determined with the logical parameter $\langle 2 / 3-2 »$. In this case load start and end detection can be described with Boolean function

$$
Y_{H \Pi}=X_{1} \cdot X_{2}+X_{1} \cdot \bar{X}_{2} \cdot X_{3}, \quad Y_{K \Pi}=\bar{X}_{1} \cdot \bar{X}_{2}
$$

according to which logical schemes are realized (fig. 4, 5). 


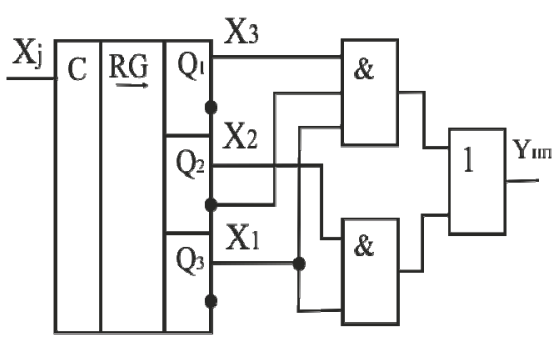

Fig. 4. Load start detector based on the logical parameter « $2 / 3 »$

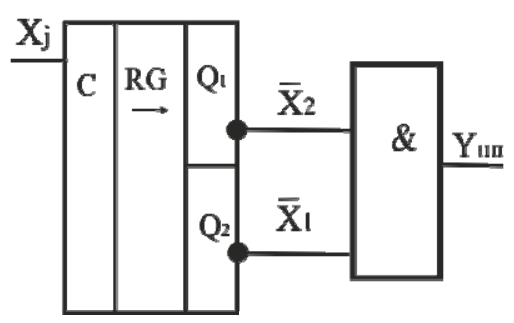

Fig. 5. Load end detector based on the logical parameter«k-2»

Coherent weight accumulation of the signal load compared to the sequential processing of a single signal allows to benefit in power for the rate signal/bar:

$$
s=\sum_{i=1}^{M}\left(\Psi_{p i}\right)^{2}
$$

Without weight processing $\left(n_{1}=n_{2}=\ldots=n_{M}=1\right)$ the formula can be put as:

$$
s^{\prime}=\frac{1}{M} \sum_{i=1}^{M}\left(\Psi_{p i}\right)^{2}
$$

The analysis of the given formulae illustrates that for any signal load with non-rectangular curve the inequality $s '<s$ is correct. Therefore, without weight processing the signal energy declines by factor of $s / s^{\prime}$, or by $10 \lg \left(s / s^{\prime}\right) \mathrm{dB}$.

Let us demonstrate processing a load of three reflected signals, for which $\psi_{\mathrm{pi}}=\{0,5 ; 1 ; 0,5\}$. We can observe that $\mathrm{s}=1,5$, $\mathrm{s} \approx 1,33$ and $\mathrm{s} / \mathrm{s} \approx 1,13$, or $10 \lg \mathrm{s} / \mathrm{s} \approx 0,5 \mathrm{~dB}$. By increasing the number of signals $(M)$ the exponent of losses remains practically the same.

For weightless processing exploiting the logical parameter «n out of $M »$ we provide assessment of accumulation quality for load signals having the same amplitude before their quantization and, hence, the same conditional probability of correct detection $D_{0}$ and false alert $F_{0}$. This suggestion simplifies calculations, whereas assessment results can easily be adjusted by decreasing the signal/bar rate, which takes into account non-rectangular load and rejection of coherent processing.

Let us determine probability $D_{i}$ of load signals $i$ overcoming the limit and the rest of signals $(M-i)$ remaining below the limit. This requirement is met by the code combinations with $i$ digits and $(M-i)$ zeros. The number of such combinations is equal to the number of combinations of $M$ elements taken $\left[C_{M}^{i}=M_{i} / 1_{i}(M-1) i\right]$. The probability of receiving one combination per signal being $D_{0}^{i}\left(1-D_{0}\right)^{M-i}$,

$$
D_{i}=C^{\prime}{ }_{M} D^{\prime}{ }_{0}\left(1-D_{0}\right)^{M-1}
$$

According to the logical parameter «n out of $M \gg$ a quantized signal load can be detected at any value $i \geq n$. This requirement is met by the code combinations including: $n$ digits and $(M-n)$ zeros, $(n+1)$ digits and $(M-n-1)$ zeros, $\ldots, \mathrm{M}$ digits and zeros. Hence, the conditional probability of quantized signal load correct detection under the logical parameter «n out of $M »$ can be determined by the following formula:

$$
D=D_{n}+D_{n+1}+\ldots+D_{m}=\sum_{i=n}^{M} C_{M}^{\prime} D_{0}^{\prime}\left(1-D_{0}\right)^{M-1}
$$

Similarly, the formula for conditional probability of false alert (probability of obtaining no fewer than вероятности получения не менее $n$ digits due to the bar) can be obtained:

$$
F=\sum_{i=n}^{M} C_{M}^{\prime} F_{0}^{\prime}\left(1-F_{0}\right)^{M-1}
$$

Since $F_{0}<<1$, the probability $F_{c}$ can be with necessary approximation evaluated by the following formula:

$$
F=C_{M}^{n} F_{0}^{n}
$$

Formulae (7), (8) allow to calculate probabilities D and $\mathrm{F}$ for the logical parameter $\left\langle n / M »\right.$ based on values $D_{0}$ and $F_{0}$.

It turns out that for every $M$ the optimal value $n_{\text {opt }} \approx 1,5 \sqrt{M}$, which gives the minimal loss in signal/bar rate. Thus logical parameter $« 2 / 3 »$ is the most suitable of all parameters of the type «n out of $3 »$, while «6/15» gives the best results compared to other « $n$ out of $15 »-$ type parameters.

Together with the analytical method, a graphic method of digital processing quality evaluation is used. Fig. 6 shows graphs of digital accumulation losses $\left\langle n_{\text {opt }}\right.$ out of $M »$ dependent on $M$ compared to coherent processing.

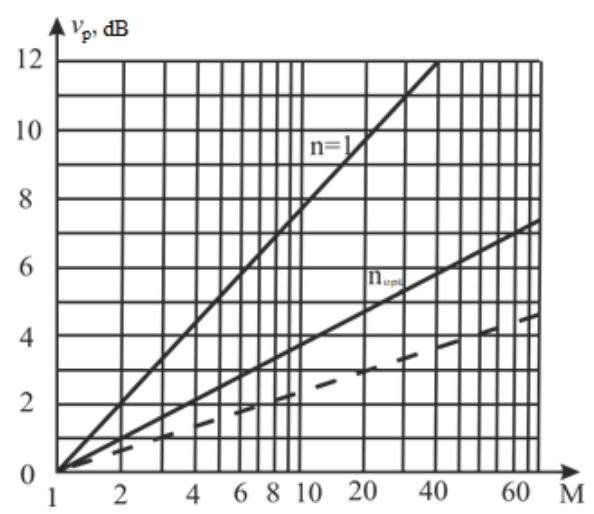

Fig. 6. Signal energy losses by digital (block curves) and analogue (dotted line) processing

The dotted line illustrates losses by non-coherent weight processing compared to coherent processing. The bold curve corresponds to the losses in digital logic detection for $n=n_{\text {opt }}$ compared to coherent accumulation. The thin block line stands for the losses of the least logical parameter «1 out of $M »$. The similarity of bold and dotted curves can give the basis for evaluation of digital processing losses compared to non-coherent weight processing.

Using "short" logical parameters «n out of $m »$, where $m<M$, additional signal energy losses occur, apart from the losses in digital accumulation « $n_{\text {opt }}$ out of $M »$. These losses correlate to the rate $\mu=M / m$, characterizing the number of separate detections for one single period of a signal load.

The separate detection using only a part of signal periods (signal energy), a decrease in detection quality can be observed. 
In terms of quantity, the number of losses in the first iteration is evaluated by the curve for $n=1$ in fig. 6 . To do this, calculating the value $\mu=M / m$ is necessary, which is used $M$. For instance, if we take the logical parameter « 4 out of 6 », for $M=17$ we obtain $\mu=2,8$, finding the value of additional losses for the «short» logical parameter, approximately $3,3 \mathrm{~dB}$.

To conclude, non-coherent (post-detection) signal load processing leads to losses in signal energy, dependent on the number of accumulated signals $M$. The value of these losses (fig. 6) allows to evaluate the potential (threshold) quality of non-coherent accumulation compared to coherent accumulation. The best of noncoherent is the signal load detector exploiting weight processing. Failure to use signal load weight processing leads to fall of the signal/bar rate. This fall, however, does not exceed $1 \mathrm{~dB}$.

Signal load digital processing leads to additional fall of the signal/bar rate. The determining factors of this fall are the transfer from analogue signal to binary quantized periods and non-complete signal load energy exploitation by logical detection methods.

\section{References}

1. Be ard Widrow, "Statistical analysis of amplitude quantized sampled data systems", Trans. AIEE Pt. II: Appl. Ind. Jan. 1961. Vol. 79. P. 555-568.

2. Pr od Jain. A Vector Quantization Multistart Method for Global Optimization. University of California, 1989. P. 37.

3. Quantizati Noise: Roundoff Error in Digital Computation, Signal Processing, Control, and Communications. P. 31.

4. Robert M. Gr and David L. Neuhoff, "Quantization", IEEE Transactions on Information Theory. Vol. IT-44. No. 6. Oct. 1998. P. 2325-2383.

5. illiam A. Pearlman, Amir Said. Digital Signal Compression: Principles and Practice. Cambridge University Press, 2011. P. 83.

6. .R. Bennett, "Spectra of Quantized Signals", Bell System Technical Journal. Vol. 27. July 1948. P. 446-472.

\title{
БЕЗВЕСОВАЯ ОБРАБОТКА ПАЧКИ КВАНТОВАННЫХ СИГНАЛОВ
}

\author{
Филатов Владимир Иванович, МГТУ им. Н.Э. Баумана, Москва, Россия, vfill0@mail.ru \\ Некрасов Александр Сергеевич, ВА РВСН им. Петра Великого, Балашиха, Московская область, Россия, \\ sanya.nekrasov.1992@mail.ru \\ Рудзит Ирина Алексеевна, МГТУ им. Н.Э. Баумана, Москва, Россия, rudzit@bmstu.ru \\ Кондрашова Дарья Александровна, МГтУ им. Н.Э. Баумана, Москва, Россия, darina.k.a@mail.ru
}

\section{Аннотация}

Оптимальные методы обработки входных информационных сигналов зачастую предусматривают операции, реализация которых крайне затруднительна и существенно повышает требования к автоматизированным системам обработки информации. Тем не менее, использование различных подходов к решению данной задачи привело к появлению синтезированных способов обработки последовательности сигналов, позволяющих без значительных усложнений аппаратной части решать задачу обнаружения с требуемым качеством. Рассмотрен способ безвесовой обработки пачек входных квантованных сигналов, который позволяет оценить потенциальное (предельное) качество обработки информации и количественно определить величину потерь этого качества при исключении тех или иных операций. Рассмотренный способ приведен с обоснованной структурой реализуемых на практике устройств. Особенностью безвесовой обработки сигналов является анализ увеличения плотности единиц на фиксированном интервале соседних позиций, что дает информацию о возможном наличии информационного сигнала. Для выявления этого фактора используются два логических критерия типа "m из m" и "n из m", которые будут описаны в данной статье.
\end{abstract}

Ключевые слова: оптимальные методы обработки, $m$ из $m, n$ из n, квантованный сигнал, безвесовая обработка, детектор.

\section{Литература}

I. Bernard Widrow, "Statistical analysis of amplitude quantized sampled data systems", Trans. AIEE Pt. II: Appl. Ind., Vol. 79, Pp. 555-568, Jan. 1961.

2. Pramod Jain. A Vector Quantization Multistart Method for Global Optimization. University of California, 1989. P. 37.

3. Quantization Noise: Roundoff Error in Digital Computation, Signal Processing, Control, and Communications. P.3।

4. Robert M. Gray and David L. Neuhoff, "Quantization", IEEE Transactions on Information Theory, Vol. IT-44, No. 6, PP. 2325-2383, Oct. 1998.

5. William A. Pearlman, Amir Said. Digital Signal Compression: Principles and Practice. Cambridge University Press, 2011. P. 83.

6. W.R. Bennett, "Spectra of Quantized Signals", Bell System Technical Journal, Vol. 27, PP. 446-472, July 1948.

\footnotetext{
Информация об авторах:

Филатов Владимир Иванович, преподаватель, к.т.н., МГтУ им. Н.Э. Баумана, факультет "Информатика и системы управления", кафедра "Защита информации", Москва, Россия

Некрасов Александр Сергеевич, преподаватель, ВА РВСН им. Петра Великого, Балашиха, Московская область, Россия

Рудзит Ирина Алексеевна, преподаватель, МГТУ им. Н.Э. Баумана, Москва, Россия

Кондрашова Дарья Александровна, студент, МГТУ им. Н.Э. Баумана, факультет "Информатика и системы управления", кафедра "Защита информации", Москва, Россия
} 